\title{
THE HISTORY OF THE GREAT SELJUK STATE IN AZERBAIJANI HISTORIOGRAPHY
}

Bayramov M.J.

\section{ИСТОРИЯ ГОСУДАРСТВА СЕЛЬДЖУКОВ В АЗЕРБАЙДЖАНСКОЙ ИСТОРИОГРАФИИ}

Байрамов Мушфиг

\section{THE HISTORY OF THE SELJUK STATE IN AZERBAIJANI HISTORIOGRAPHY}

Резюме. История Государства Сельджуков, сыгравшего значительную роль в политической, экономической и культурной жизни Ближнего и Среднего Востока в средние века, является одной из самых актуальных проблем Азербайджанской историографии.

Как известно, после создания турками государства сельджуков их основной политикой было продвижение на запад, захват Анатолии, превращение Анатолии в турецкие земли. Кавказский регион был воротами в Анатолию. Поэтому Кавказ, как и Азербайджан, имел большое военно-стратегическое значение для сельджуков.

После победы Данданекана на конгрессе в Мерве было решено начать новые военные операции на Востоке и Западе. Главной целью атаки были Иран, Византия и Южный Кавказ, потому что эти страны находились в политическом беспорядке и не могли им противостоять. Наступавшие на Кавказ войска сельджуков вскоре покорили местные феодальные государства. Азербайджанский народ, находившийся под властью государства сельджуков более века, сыграл особую роль в политическом и культурном развитии государства сельджуков.

Однако эта проблема в отечественной историографии стала отдельной темой исследования только во второй половине XX века, что давно осталось вне поля зрения. Настоящая статья посвящена изучению Государства Сельджуков в Азербайджанской историографии. В статье исследуются труды выдающихся Азербайджанских историков 3. Бунядова, Р. Гусейнова, Н. Ахундова, Н. Алиева, Ш. Мустафаев, И. Гаджиев, Т. Достиева и других, проводивших исследования в этой области со второй половины. от двадцатого до первого десятилетия двадцать первого века и их роль в изучении истории великого государства на средневековом мусульманском Востоке, государства сельджуков.

Summary. The history of the Seljuk state, which played a significant role in the political, economic and cultural life of the Near and Middle East in the Middle Ages, is one of the most actual problems in Azerbaijani historiography.

As it is known, after the establishment of the Seljuk state by the Turks, their main policy was to advance to the west, to seize Anatolia, to turn Anatolia into Turkish lands. The Caucasus region was the gateway to Anatolia. That is why the Caucasus, as well as Azerbaijan was of great military-strategic importance for the Seljuks.

After the Dandanekan victory, it was decided at the Congress in Merv to launch new military operations to the East and West. The main target of the attack was Iran, Byzantium and the South Caucasus, because these countries were in political disarray and unable to resist them. Seljuk troops advancing on the Caucasus soon subjugated the local feudal states. The people of Azerbaijan, who have been under the rule of the Seljuk state for more than a century, have played a special role in the political and cultural development of the Seljuk state.

However, this problem in national historiography has been a separate research topic only in the second half of the 20th century, which has long been out of sight. The present article is devoted to the study of Seljuk state in Azerbaijani historiography. The article studies the works of prominent Azerbaijani historians Z. Bunyadov, R. Huseynov, N. Akhundova, N.Aliyeva, Sh.Mustafayev, I.Hajiyev, T.Dostiyev and others, who have done research in this area since the second half of the twentieth to the first decade of the twenty-first century and their role in the study of the history of the great state in the medieval Muslim East, the Seljuk State, has been defined.

Ключевые слова: Государство Сельджуков, Азербайджан, историография, турки, мусульмане

Keywords: Seljuk State, Azerbaijan, Historiography, Turkish, Muslim

The Muslim-Turkic state Seljuk Empire, which formed in the Middle East in the 11th century, played an important role in the political, economical and cultural life of many peoples. Azerbaijan was one of the countries located in the geographical area dominated by the Seljuk state. In this regard, study the history of the Seljuks state has always been relevant in Azerbaijan historiography. However this problem has been studied since the second half of the twentieth century and is still in its infancy. In Azerbijan historiography Z.Bunyadov, N.Akhundova, N.Aliyeva, T.Dostiyev, R.Huseynov, Sh.Mustafayev, E.Mammadov, I.Hajiyev, A.Ismayilova and others conducted research on this topic.

Academician Z.Bunyadov was one of the first researchers of the Seljuk period in Azerbaijani historiography. The monograph of the prominent orientalist "The state of the Atabeys of Azerbaijan in 1136-1225" published in 1978 is very important in this regard. Using medieval Arabic sources and numerous works writen by modern historians of Azerbaijan, 
Turkey, Russia and Western Europe of on the history of the Seljuk state, the author conducted research on various problems of the Seljuk state and provided very interesting information in his monograph [1].

Ziya Bunyadov also translated into Russian the 13th century author Sadradin Ali Abul Hasan Ali ibn Abul Favaris Nasir ibn Ali al-Husseini's work on the history of the Seljuk state, "Akhbar ad-Davlat al-Seljuk (News about the Seljuk state)" [2] .

Rauf Alisher oglu Huseynzadeh is one of the researchers who made a great contribution to the study of the history of the Seljuk state in national historiography. His works of "Caucasians and Seljuks", "Seljuk epoch of the history of the Caucasus", "Seljuk theme in modern historiography", "Beliefs, customs and rites of the Turks of the 7th-12th centuries (according to Syrian sources)", "The Caucasus and the Great Turkic Empires", "Seljuks in the Caucasus", "Manzikert and the Caucasus", and others are of great scientific importance in the study of the history of the Seljuk state.

One of his extensive research works on the history of the Seljuk state is the Caucasus and the Seljuks ("Кавказ и Салдьжуки"), published in 2010. In this work which is of great scientific importance in Caucasian historiography, the historiography and ethnography of the Seljuk period of the Caucasus, the political history of the XI-XII centuries, typological features of socio-economic relations, the trade and tax system, was studied in detail based on historical sources. Stating that in the first period the Seljuk was no centralized state the author writes that in that time this state consisted of nations divided among the Seljuk princes. Each of them accepted the supreme authority of the Great Seljuk Sultan, took part in the battles at his request, and paid a certain amount of money to the treasury from the spoils of war. However, in their internal affairs, each nation was independent[3, p.16].

R. Huseynov is also the author of numerous scientific articles on various problems of the Seljuk state. One of them dedicated to the Battle of Manzikert, which caused a great change in the political history of the world and has always been in the focus of historians, is "Manzikert and the Caucasus". The article deals with the political situation in the Caucasus in the early 11th century, the first Turkish marches to the Caucasus, the Battle of Manzikert, its consequences, the importance of the conquest of the Caucasus and Asia Minor for the Seljuk state, etc[4].

As it is known, after the establishment of the Seljuk state by the Turks, their main policy was to move west and seize Anatolia. The Caucasus region was the gateway to Anatolia. The Turks made their first marches to the Caucasus in the first decades of the 11th century, during the reign of Alp Arslan's grandfather Chagri Bey, before the establishment of the Seljuk state. As a result of their victory in Dandanakan in 1040, the Seljuks, who established a state in Khorasan, expanded their marches to the Caucasus. During the reign of Sultan Alp Arslan, the Seljuks conquered a number of territories in the Caucasus and established themselves here. The Byzantine Empire, in turn, wanted to return lost territory in the Caucasus and keep these terretories in hand. The wars waged by Byzantium for this purpose weakened him. R. Huseynov points this as one of the reasons for the defeat of Byzantium in the battle of Manzikert.

Emphasizing that the victory in the Battle of Manzikert was more important for the Seljuks than the Battle of Dandanakan, the author said that after this there were no serious obstacles for the Seljuks to carry out their plans for occupation in the East. Thus, by defeating the military forces of the Byzantine Empire in the battle of Manzikert by Alp Arslan, the Turkish-Islamic union won a decisive victory over the Byzantine Empire and the Armenian-Georgian feudal lords who tried to seize Azerbaijan [4, p.68].

As academician Y.Mahmudov wrote, "The policy of the Byzantine Empire, strengthening in the South Caucasus and the plans of aggression of Armenian and Georgian feudal lords tr63ying to seize the western lands of Azerbaijan relying on this Christian state failed. The plan to bring the entire South Caucasus under the influence of Christianity failed. The Christian factor, in general, declined in the South Caucasus" [5, p.9].

One of Rauf Huseynov's articles on the history of the Seljuk state is called "The subject of Seljuk in modern historiography." This article, published in 1970, covers the issues of historiography of the history of the Seljuk state up to that time. It should be noted that the problem was not sufficiently studied during the period of R.Huseynov's address to the subject, and the research works written on this topic were a minority. Nevertheless, the author researched scientific works on the history of the Seljuk state in Western European, Turkish and Soviet historiography until the 1970s and commented on their historical role[6].

Services of Professor Shahin Mustafayev in the study of the history of the Seljuk state is also noteworthy. His work "From the Seljuks to the Ottomans: ethno-political processes in the Turkish environment of Anatolia in the XI-XV centuries" is very important in this regard.

The first half of the first chapter of the work entitled "Turks in the Middle East during the Seljuk period" provides information about migration of turkic ethnoses in different historical periods to Northern China, Eurasian steppes, Northern India, Middle East, Eastern Europe, the emergence of the first Turkic states, the sources in which the Turkic ethnonym was first encountered, the first source in which the Turkic ethnonym was used as a term covering all Turkic ethnoses, the first Turkish written monument and so on.

The author explains the establishment of the Great Seljuk Empire by the accepting of the Oghuz Turks the religion of islam. He also notes that the term Turkmen, which has been widely used in sources since the 10th century, has also been used as a term to express the Seljuk Oghuzs who accepted Islam. However, Mustafayev said that Muslim Oghuzs who migrated to the Middle East, including Azerbaijan and Anatolia, have not yet called themselves Turkmens, Turkmans 
continued to use the old Oghuz horonym. This opinion of the author is found in both medieval sources as well as in modern historiography[7].

Historian Fazlullah Rashid al-Din states in his "Oghuzname" that the term "Turkmen" was used as a term to refer to all Oghuzs. The Oghuzs, who have been living in Azerbaijan, Turkmenistan, Turkey, Iran and Iraq since the 11th century, are the ancestors of the Turkic peoples. The leaders of the Seljuk and Ottoman dynasties also came from them" [8, p.4].

Turkish historian Faruk Schumer writes in his book Oguzes: "The religion of Islam, widespread since the 10th century, has also been adopted by the vast majority of Oguzes. As a result, the Oghuz began to be called "Turkmens" from the 11 th century[9, p.11].

In the second half of the book "Conquest of Anatolia by the Turks" Shahin Mustafayev describes the process of Turkification of Anatolia, which affected the ethno-political history of the entire Middle East and resulted in a change in the ethnic face of Anatolia, the gradual Turkification of these territories. The author rightly noted that the process of Turkification of Anatolia is not a sudden event, but a process that combines complex social, religious and ethno-cultural factors spanning several centuries.

In the study of the history of the Seljuk state, the scientific research work of academician N.Akhundova "History of the Caucasus and the Great Turkish Empires" co-authored with Professor R.Huseynov is of both scientific and political significance for our national historiography. The relations between the Caucasus and the Turkic empires that emerged at different stages of historical development examined in the work. Dedicated a separate chapter to the history of the Seljuk state, which is called "The Caucasus and the Seljuks" in the article. Marches of the Great Seljuk State to Caucasus, occupation of the region by Seljuks, relations of Seljuk state with Caucasian states and etc. reflected here[10].

The work of historian and researcher Akbar Najaf "The history of Seljuk states and ancestors (From the emergence of the Oghuzs - to the XIV century)" wrote on this subject is also noteworthy. The book contains sections the Seljuk government in Azerbaijan, the Kipchak government in Georgia, the emergence of the Ildegizids state, the development and collapse of the Ildegizids state and cultural life during the Ildegizids period.

In the section entitled "Cultural life in the era of the Ildegizids", the author provides valuable information about the development of Azerbaijani culture at a time when the Muslim renaissance was flourishing. The author expressing his attitude to the idea of the Azerbaijani well-known historian Ziya Bunyadov that said about the Seljuk sultans "The Seljuk sultans, as well the Atabeys, who later replaced them, were representatives of the nomads who protected the tribal structure and spok in the Turkish languages, which has not writing" state that this is not true.

By pointing out that the famous work of Mahmud of Kashgar "Divan Luqat-it Turk" was written in Baghdad during the Great Seljuk period, he notes that the Seljuks had writings[11, p.49].

Well-known Turkish historian Osman Turan referring to Fehraddin Mubarakshah, who lived in 1145-1248, writes in his book "History of the Seljuks and Turkish-Islamic civilization" that the Turks have alphabet and books. One of the alphabets they taught their children was the Sogdian alphabet, which consisted of twenty-five letters, and the other was the non-contiguous Doqquz-Oguz alphabet, which was written from right to left and consisted of twenty-eight letters. O. Turan later writes with reference to Ibn Nadim that when the Turkish sultans wanted to write to the yabgu and beys, they would call their viziers and order them to write and embroider on it [13, p.341-342].

It is clear from the information that the Seljuk Turks had writings, but the first Seljuk sultans were illiterate. This idea was confirmed by the orientalist N.Aliyeva in her book "Islamic culture in Azerbaijan": Despite their (ie Seljuk) high appreciation of science and literacy, "... everyone from the Seljuks to Sanjar was illiterate" [12, p.171-172].

Academician Ismail Hajiyev is one of the historians who studied the history of the Seljuk state. In his article "Azerbaijan Atabeylar state and Nakhchivan" he gave information about the establishment of the Seljuk state, its conquest of Nakhchivan along with other territories of Azerbaijan, Nakhchivanshah Abu Dulaf's vassal dependence on it, the abolition of the Nakhchivan kingdom into the Seljuk province during the raign of Alp Arslan, the activities of Malikshah I, Mohammad Tapar the sultans of the Great Seljuk state, the transformation of Nakhchivan into a crown city of the Azerbaijani Atabeys Eldeniz dynasty after the disintegration of the Great Seljuk Empire, the political, economic and cultural role of Nakhchivan in the life of the Azerbaijani Atabeys.

The author notes that Togrul Bey, the founder of the Seljuk state, captured Nakhchivan during his march to Azerbaijan in 1054 and succeeded in recognizing Nakhchivan Shah Abu Dulaf as a vassal of the Seljuks. After that, Alp Arslan, who ascended the sultanate throne, made his first visit to Nakhchivan and put an end to the Nakhchivan kingdom in 1064 and appointed his emir to Nakhchivan[14, p.43].

In her book "Nakhchivan from the Arabs to the Mongols", Naila Valikhanli, referring to the work of the 13th century author Ali al-Husseini "Akhbar ad-daulat as-Seljukiyya", writes that The poet Tusi Ali Asadi, who dedicated his work "Garshasb-nama" to Abu Dulaf, met with Nakhchivan Shah Abu Dulaf in his palace two years after Alp Arslan's occupation of the Nakhchivan kingdom [15, p.26]. This fact gives grounds to say that after the second Seljuk sultan Alp Arslan occupied Nakhchivan, the Dulafis ruled Nakhchivan as a Seljuk emir for some time.

One of the works written on this topic in Azerbaijani historiography is T. Dostiyev's article entitled "The situation of urbanization in the Muslim world in the Seljuk period and the urban culture in Azerbaijan." The article examines the level 
of urban planning and cultural development in Azerbaijan during the Seljuk period. The author states that during the Seljuk period, as in the Muslim East, the process of urbanization in Azerbaijan accelerated and reached its highest level of development, the "Renaissance". T. Dostiyev notes that the cities of Ganja, Nakhchivan, Tabriz, Shamakhi became economic, political and cultural centers not only in the Caucasus but also in the Muslim East during the urban planning activities of the Seljuk sultans and their ancestors [16].

Nargiz Aliyeva has a special contribution to the study of the history of the Seljuk period in Azerbaijani historiography. A semi-chapter of N.Aliyeva's book "Islamic culture in Azerbaijan" dedicated to the Seljuk period. The activity of the Seljuks in the spread of Islam, the development of science and culture is described in detail in the work[12]. The author states that the Seljuk rulers highly valued science, poetry and art, and generously rewarded the masters of speech.

One of the works devoted to the history of the Seljuk state in Azerbaijan historiography is the article titled "Descriptive motifs of Seljuk period ceramics in Azerbaijan" written by Aida Ismayilov, an employee of the National History Museum of Azerbaijan. In the article, the author studied the illustrated ceramic samples of the Seljuk period found out in the medieval settlements of Beylagan, Gabala, Ganja, Bandovan and other cities, preserved in the National History Museum of Azerbaijan.

The researcher divides the descriptive pottery samples of the Seljuk period into two groups, anthropomorphic and zoomorphic. Since most anthropomorphic pottery specimens are associated with hunting scenes, the author rightly states that it is related to the hunting, one of the favorite entertainment of the Seldjuks[17].

One of the researchers of the Seldjuk state is E.Mammadov. His textbook "The Seljuks" is an important source in the study of this period. Using numerous literatures written in different languages and the medieval historical sources, the author gave generalized information about the establishment of the Great Seljuk Empire, its invincible invasions of Central Asia and Iran, the battles of Dandanakan, Manzikert, the establishment of the Anatolian Seljuk state, its struggle against the Crusaders, the third and fourth crusades, the invasion of Anatolia by the Mongols, the state organization in the Seljuks, their administrative functions, the symbols of power in the Seljuks, etc. in this book[18].

Thus, the study of the history of the Muslim Turkic states, including the Seljuk state, which left a great mark on the history of Azerbaijan, has recently become one of the most relevant topics in our historiography. Although the first steps in this field were taken in Azerbaijan during the Soviet period, thorough research in this field was conducted during the years of independence. However, it should be noted that the study of this problem in national historiography is still in the early stages.

\section{Used literature}

1. Bunyadov. Z.M. State of the Atabeks of Azerbaijan (1136-1225). Baku, Science, 2006

2. "Akhbaru-d-daulati-s-Seljukiya" by Al-Husseyni, edited by Z.Bunyadov, Baku, 1980

3. Huseynzadeh R. The Caucasus and the Seljuks. Baku, Caucasus, 2010

4. Huseynzadeh R. Manzikert and the Caucasus. Ankara, 1968

5. Mahmudov Y. The Azerbaijanis (general view of ethnic-political history). Baku, Azpoligraf, 2008

6. Huseynzadeh R. Seljuk theme in modern historiography. Turkological collection. Moscow, 1970

7. Mustafayev Sh. From the Seljuks to the Ottomans. Ethno-political processes in the Turkish environment of Anatolia in the XI-XV centuries. Baku, Science, 2010

8. Fazlallah R. Oguzname. Baku, Science, 1987

9. Sumer F. The Oghuzes. Ankara, 1992

10. Nargiz A., Huseynzade R. The Caucasus and the great Turkic empires. Baku, 2012

11. Najaf A. The history of Seljuk states and Atabeys (from the emergence of the Oghuzes to XIV century), Baku, Law, 2010

12. Aliyeva N. Islamic culture in Azerbaijan. Baku, Science and education, 2017

13. Turan O, The Seljuk history and Turkish Islamic civilization. Istanbul, 1969

14. Haciyev İ. Azerbaijan state of Atabeylar and Nakhchivan, Tafakkur, 2016

15. Valikhanli N. Nakhchivan from Arabs to Mongols. Baku, 2005

Dostiyev T. The situation of urbanization in the Muslim world during the Seljuk period and urban culture in Azerbaijan. // XIV Turkish Historical Congress. Ankara, 2005

17. Ismayilova A. Illustrative motifs in the Seljuk period ceramics of Azerbaijan (based on the materials of the National Museum of History of Azerbaijan of ANAS), "Research, promotion, protection and restoration of national values preserved in museums, archives and libraries" dedicated to the 95th anniversary of National Leader Heydar Aliyev Proceedings of the scientific conference. Baku, 2018

18. Mammadov E. The Seljuks. Baku, 2005 